\title{
Biodiversity boss to stay, averting crisis
}

[LONDON] The executive secretary of the United Nations (UN) Convention on Biological Diversity was on the verge of leaving his post this week as simmering tensions between the convention secretariat in Montreal and its parent organization, the UN Environment Programme (UNEP) in Nairobi, came to the boil.

Calestous Juma has been persuaded to stay on temporarily, but only after a lastminute intervention by members of the convention's nine-country governing Bureau who met in emergency session on Monday (1 September) with Juma and a senior official from UNEP.

The Bureau's move has saved the convention from crisis - at least for the time being. Juma's departure would have put back the convention's progress on important issues, including negotiations towards a legally binding protocol regulating the safety of genetically modified organisms. His departure might also have further delayed ratification of the convention by the United States. The Bureau's move will now have strengthened his hand in his protracted tussle with UNEP over how the convention should be run.

UN insiders say Juma had decided to leave after a confidential appraisal from a UNEP ombudsman towards the end of his two-year contract criticized his performance. He was offered a one-year extension. He turned down the offer, and prepared to leave at the end of September.

But at Monday's meeting, Bureau members voiced their anger at UNEP's plans to let Juma leave, which they refused to accept on

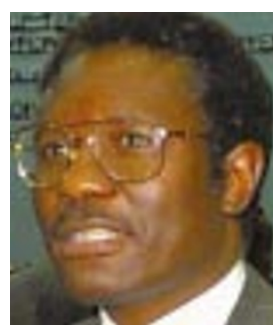

the grounds that they were made without consulting the Bureau. One representative of a European Union state says that UNEP's executive director, Elizabeth Dowdeswell, had not followed the Juma: staying in place, accepted procedure for the time being.

for staff evaluation, or for the appointment of an executive secretary. "Basically, UNEP will have to go through the whole evaluation process again in full consultation with the Bureau, and extend the executive secretary's contract until the process is finished," says the representative, who declined to be identified.

With the immediate crisis averted, attention will now turn to the reasons why the biodiversity convention faced the loss of its second executive secretary in two years. Juma's threatened departure mirrors that of his predecessor, Angela Cropper, and centres on a dispute between Montreal and Nairobi over Montreal's attempts to win greater autonomy in implementing the decisions of the convention's 169 member countries - a responsibility that currently rests with UNEP.

"Juma is not allowed to communicate directly with countries without the authority of UNEP, yet has to carry out their directives. He also has little control over recruiting staff, or running conferences, which is also done by UNEP. Yet, when things go wrong, he has to carry the can," says one official.

Many countries are keen to be able to con- duct business with the executive secretary without UNEP looking over their shoulder. Some feel that their success in persuading UNEP to reconsider its decision to let Juma depart represents an important first step in that direction. But legal experts say that, under the convention's rules, UNEP's executive director has complete and final authority to hire and fire whom she likes.

One leading environmental lawyer says the best way to resolve this dispute once and for all is for the convention's annual conference to agree, preferably by consensus, to sack UNEP as the convention's host secretariat. The convention's executive secretary would then be appointed directly by the UN secretary general, in the same way that he appoints the head of the UN's climate convention. Climate convention member countries play a far more direct role than those in the biodiversity convention.

But arriving at a consensus on this issue will not be easy, nor will the task of choosing an alternative secretariat, "as people are not exactly queuing up to do the job", says the lawyer.

UNEP declined to comment. However, sources close to the organization acknowledge that the executive secretary's job "is not an easy one". They add that autonomy from UNEP would not necessarily make the biodiversity convention function more effectively, as UNEP would have to be replaced by another UN supervisory body. "People think that the climate convention is independent and controlled by the parties. But it answers to the UN," says one official.

Ehsan Masood

\section{Animal researchers should 'start talking' to anti-vivisectionists}

[LONDON] One of the founders of the Boyd Group, a forum representing the centreground in the animals-in-research debate in the United Kingdom, has called for the organization to talk to ardent antivivisectionists, possibly opening a line of communication to the extremist Animal Liberation Front (ALF). The suggestion will be discussed at a group meeting next week.

The call was made by Colin Blakemore, professor of physiology at the University of Oxford. Blakemore is president-elect of the British Association for the Advancement of Science, whose annual science festival at the University of Leeds will host the Boyd Group's first public meeting on 9 September.

Reaction from other members of the group to Blakemore's idea has been mixed. Les Ward, director of the moderate animal rights organization Advocates for Animals, and a co-founder of the Boyd Group, says he does not oppose talking to the ALF. But
Ward says he doubts whether dialogue will result in progress given that the ALF is unlikely to renounce violence as a means of stopping animal experiments.

But Mark Matfield of the Research Defence Society, which represents organizations involved in medical research, says he is completely opposed to any contact with the ALF. "I don't think you can have dialogue with an organization that wants to blow you up," he says.

Blakemore, who along with his family has been a target of ALF violence for many years, says he is prepared to "talk to almost anyone" to achieve progress in the debate. "I am perfectly prepared to see the ALF at the table if their attitude is constructive and there is a chance of progress."

Blakemore says the Boyd Group needs to "move forward" and tackle "more contentious" issues. The group so far has agreed to reduce the numbers of animals used in research within the organizations it represents.

The group has in the past sought the support of mainstream anti-vivisectionist organizations, such as Animal Aid, and the British Union for the Abolition of Vivisection. But, despite keen interest during preparatory discussions, both organizations have said they are not prepared to join unless a total ban on the use of animals is on the agenda.

Blakemore says these organizations could use the group as an opportunity to convince their critics of the strength of their case. But Bob Coombe, scientific director of the Fund for Replacement of Animals in Medical Experiments and a member of the Boyd Group, says wider membership, although important, might also inhibit progress. "One might argue that we could become a talking shop if every single organization is represented," he says. 